\title{
Engineering Ethics Education and Moral Education Reform in Universities of Science and Engineering
}

\author{
Wenduo Zhao ${ }^{1}$ \\ ${ }^{1}$ School of Humanities, Economics and Law, Northwestern Polytechnical University, \\ Xi'an, 710072, PR China
}

\begin{abstract}
In the context of a materialistic, profit-driven, and market-oriented society, students' poor humanistic quality is the major problem in moral education reform in universities of science and engineering. Therefore, improving students' humanistic quality has become a priority in the reform. Engineering ethics education follows the philosophy that teaching students to think in an ethical way is equally important as teaching students knowledge and skills, which helps convert students mindset from a pragmatic perspective to a value-oriented perspective. Therefore, engineering ethics education should be given due attention and further explored in moral education reform in universities of science and engineering.
\end{abstract}

Keywords: Engineering ethics education, Universities of science and engineering, Moral education reform

\section{Introduction}

In the context of a materialistic, profit-driven, and market-oriented society, students' poor humanistic quality is the major problem in moral education reform in universities of science and engineering. Therefore, improving students' humanistic quality has become a priority in the reform. Facing a group of students who adopt the logic-dominant way of thinking, you will find it impossible to implement the real moral education, let alone instilling into their minds the socialist core values.

\section{Pragmatic motivation of moral education reform in universities of science and engineering}

Cultivating innovative and professional talents with firm ideal, belief and humanistic quality is supposed to be the basic educational objective of science and engineering universities. Nevertheless, the "dual track" (Marxist theory and ideological and moral courses being on track, while engineering knowledge and skills course being another) educational mode which is being practiced has deviated from this objective. On the one hand, Marxist theory and ideological and moral courses are featured by abstract lecturing, which is not effectively connected with specialized courses. Consequently, Marxist theory and ideological and moral courses fail to achieve the teaching objectives. At present, discussion about moral education reform in universities of science and engineering mainly focuses on how to make Marxist theory and ideological and moral teaching more effective. In this context, moral education reform in universities of science and engineering should start from guiding students to realize the humanistic concern of Marxism and the leading role of Marxist values.

On the other hand, engineering knowledge and skill courses have become workers and craftsman training courses because of the lack of attention to engineering ethics education. Too much emphasis is paid to traditional engineering education that engineering and professional ethics education has been neglected. Therefore, there is the triple crisis of value rationality, selection rationality and practical rationality. [1] Currently, education of science and engineering universities follows the scientism vision, which aims at cultivating graduates who can contribute directly to the society, such as engineers, physicists or technicians. [2] Teaching of science and engineering universities focuses too much on engineering knowledge and skills instruction to the neglect of ethics instruction. If this trend continues, students of science and engineering, who have not received sufficient humanistic education in high schools, will consider skills to be the most important in learning and eventually become humanistic value-deprived machine-like workers. Such education has deviated from the highest ethics principle of "engineering serves people".

\section{Value function of engineering ethics education}

Engineering ethics education and engineering skills education are both high-level professional quality education and are indispensable parts of engineer education in higher learning institutions. Teaching students to think in an ethical way is equally important as teaching them knowledge and skills. Basic content of engineering ethics education include the sense of responsibility of "putting quality and safety first", the duty of thinking thoroughly, and the esthetic dimension. Engineering technology serves people's life, so scientific, economic and ethical elements are embedded in technology itself. A good engineering product carries with it the ethical concern of designers and managers. The sense of responsibility of "putting quality and safety first", which is emphasized in engineering ethics, shows the respect for life. The duty of thinking thoroughly 
is concerned with maximization of benefits. The esthetic dimension, which pays attention to the beautiful appearance of products, aims to satisfy people's esthetic appeal. From a theoretical perspective, engineering ethics education in higher learning institutions should cultivate students' engineering ethics quality and improve their decision-making ability so that they are equipped with the sense of engineering ethics and standards. In practice, engineering ethics of students of science and engineering are guided by the value dimension of engineering ethics education.

"Engineering ethics education includes natural ethics, discourse ethics, and ethics of responsibility. This classification is based upon the practical ethics and value relationship in current engineering activities. Natural ethics are concerned with the relationship between man and nature. Discourse ethics is related to the relationship among human beings. Ethics of responsibility is targeted at the relationship between man and society and between individual and oneself."[3] Engineering ethics involve the relationship among oneself, others, nature, and society, and therefore can best demonstrate the value effect of engineering ethics education. "Engineering ethics education is an important carrier to link knowledge with experience, and also a guarantee for implementing diversified values. If we still simply take into consideration economic returns and economic value in engineering ethics education, excluding practical issues concerning nature, history, culture, aesthetic appreciation, and morality, the ideals of moral value hereby will weakened and the value of engineering ethics education as a supplement to engineering education will be brought into questioning. Therefore, it is a must for the engineering education reform to develop the system of engineering ethics from three dimensions, including natural ethics, discourse ethics, and ethics of responsibility. "[4] Marxism ethics emphasize a comprehensive, coordinated and sustainable relationship among man, nature and society. In this sense, engineering ethics education, which is based upon a three dimensions of natural ethics, discourse ethics, and ethics of responsibility, is consistent with Marxism ethics. For this reason, enhancing engineering ethics education of science and engineering universities under the guidance of Marxism ethics and on the basis of professional engineering knowledge will help develop students' patriotic awareness, creativity, humanistic quality, scientific research spirit, and teamwork spirit.

\section{Examine moral education reform of science and engineering universities from the perspective of engineering ethics education}

Since higher engineering education aims at cultivating engineering professionals, for whom value rationality and instrumental rationality are equally important, engineering ethics education deserves to be a basic and important part of university moral education. "At the moment, moral education in Chinese universities mainly focuses on Marxist theory and moral courses, which is required to keep the higher education in the right direction and to cultivate socialist builders and successors. However, moral education in Chinese universities fails to distinguish itself from that in elementary and high schools. To reform university moral education is by no means overturning the current system to start a new one. Nevertheless, for the purpose of cultivating professional talents and promoting professional ethics education, we should re-examine the objective and content of current university moral education and make necessary changes and adjustment so as to make it in line with the development of the times. Doing so is absolutely beneficial."[5] The "two courses" (Marxist theory course and ideological and moral course) are so abstract that they have weakened the original function of university political and moral education. However, engineering ethics education can serve as a platform linking political and moral education and professional education, incorporating engineering ethics into the objective, curriculum and practice of moral education of science and engineering universities. This will help students to connect moral value with knowledge and skills, breaking the impression of abstract lecturing in moral education and improving students' engineering ethics.

Firstly, objectives of engineering ethics education should be introduced in the objectives set for moral education of science and engineering universities. "The moral education objectives listed in the Guidance of University Moral Education issued by former Ministry of Education have two new characteristics. One is that principles are set for students' political directions, worldviews, life philosophy, and moral standards; The other is that excellent members will be selected and cultivated while conducting political and moral education among all students."[5] However, although university moral education differs from moral education in elementary and high schools in that the former has engineering ethics education, the above objectives do not show such a distinction. Therefore, to improve engineering ethics of science and engineering students, enhance their judging and decision-making ability, we should include objective of engineering ethics in the objectives set for moral education of science and engineering universities. On the one hand, general objectives set for moral education of science and engineering universities can serve as the guiding principle for engineering ethics education; on the other hand, objective of engineering ethics education should be integrated with the teaching objectives of "two courses" (Marxist theory course and ideological and moral course). For example, "astronauts' spirit" should not only be used as a way of political propaganda to unite people, but also be used to raise awareness of quality and safety. Teachers also should change their own mindset to pay due attention to engineering ethics education. Science and engineering 
universities should make more efforts to cultivate and attract engineering ethics teachers. Relevant education authorities should make engineering ethics education as important index in evaluating and assessing moral education of science and engineering universities.

Secondly, engineering ethics courses should be included in the moral education curriculum of science and engineering universities. "Curriculum design is the key to achieve teaching objectives. A scientific curriculum should not only serve the teaching objectives, but also be conducive to students' psychological development. At present, specialized courses take up a big proportion, and moral courses also occupy a considerable percentage. To add compulsory ethics courses, though necessary, seems to be rather difficult. "[5] Moral course reform should avoid imposing extra burden upon students and wasting existing resources. Therefore, within current curriculum, engineering ethics education can be conducted in multiple ways. For example, engineering ethics can be included in "two courses" (Marxist theory course and ideological and moral course). Specialized courses can also include content of engineering ethics. Optional engineering ethics courses can be opened where teachers with both sufficient specialized knowledge and admirable ethics can develop students' ethics awareness and decision-making ability through discussions or seminars.

Last but not least, implementation of engineering ethics education should be included in implementation of moral education in science and engineering universities. Success of university moral education largely depends on the implementation process, which is also the focus of engineering education. In the past, teaching activities and moral education practice were separated in engineering education. As a result, the former turn out to be "a means to nowhere", and the latter seem to be "an end without means". Actually, engineering ethics education can effectively combine teaching activities and moral education practice. "This requires that professional teachers and moral educators work together to guide students to pay attention to social and ethical issues related to the specialized knowledge and skills they learnt, and organize discussions and analysis of these issues so as to improve students' judging and decision-making ability." [5]

\section{Conclusions}

Engineering ethics education follows the philosophy that teaching students to think in an ethical way is equally important as teaching them knowledge and skills, which helps develop students' humanistic quality and convert their mindset from a pragmatic perspective to a value-oriented perspective. Therefore, engineering ethics education should be given due attention and further explored in moral education reform in universities of science and engineering. Potential functions of engineering ethics education should be brought to full play as a result of the long-time weakening trend hereby. The value function of engineering ethics education should be paid due attention in moral education reform in universities of science and engineering by incorporating engineering ethics education elements into objective-setting, curriculum design, and class instruction of moral education in universities of science and engineering.

\section{References}

[1] Yunhong Zhao, "Three rational dimensions of higher engineering ethics education," Studies in Dialectics of Nature, vol.10, pp. 43, 2011.

[2] Yaqing Mao, Three perspectives in education Studies (Hefei: Anhui Educational Press, 2012), pp. 341.

[3] Xinming Duan, "Three value dimensions of engineering ethics education," Studies in Dialectics of Nature, vol.3, pp. 71, 2010.

[4] Xinming Duan, "Three value dimensions of engineering ethics education," Studies in Dialectics of Nature, vol.3, pp. 72, 2010.

[5] Xiaoyan Dong\& Jianmin Gu, "Professional ethics education and university moral education reform," Science of Education, vol.5, pp. 45, 2001. 